Mondouli, Republic of the Congo (Brazzaville), or Mr. John M. Jansen, c/o Department of Anthropology, University of Chicago, Chicago, Illinois, U.S.A.

(Abridged from a communication by Mr. John M. Janzen)

\title{
First African Population Conference, Ibadan, Nigeria, January 1966
}

THE conference was sponsored and made possible by the Population Council of New York and excellently organized by Dr. Okonjo of the Centre of Population Studies, University of Ibadan, and Dr. Caldwell of the Australian National University. It provided the opportunity for some one hundred persons concerned with African population studies-demographers, sociologists, medicals, geographers, and others-to meet for inter-disciplinary discussion in this broad field. Representatives from eleven English-speaking countries and from twelve universities in tropical Africa were present, together with a number of students of African population from overseas. Preparatory to the conference more than fifty papers were submitted and these were circulated to participants. At the conference itself it was thus possible to apportion the major amount of time to discussion. This was always lively and valuable, and covered a wide range of topics-problems of census and planning for the next round of censuses, the need for vital statistics, and accelerating rates of population change to receive greater attention in development plans, being among the more important. Several visits of demographic interest were arranged in and around Ibadan. A most useful opportunity was provided for the interchange of ideas and information and in conclusion the conference passed a number of resolutions. These concerned the importance of reprinting Kuczynski's classic Demographic Survey of the British Empire with comments on this work in the light of current information, making available data with a central library of deposit for these in each African country, forming an association of statisticians and publishing a journal, and the urgent need for improving conditions for demographers and statisticians in government service in Africa. Papers submitted for the conference, together with the discussions, are being edited for publication, it is hoped, in 1967 .

(Communicated by Dr. R. Mansell Prothero)

\section{'The Small Brave City-State'}

WE have received the following comments on the review by G. I. Jones of The Small Brave City-State: a History of Nembe-Brass in the Niger Delta, by Ebiegberi Joe Alagoa (Africa, xxxvi. 3, I966, pp. 339-40):

Dr. E. J. Alagoa (Institute of African Studies, University of Ibadan) writes:

'Allow me to make a few comments about Mr. G. I. Jones's review of my book, The Small Brave City-State: a History of Nembe-Brass in the Niger Delta.

'Mr. Jones strikes me as a man trying to stake out claims to territory, and therefore intolerant of trespassers. He has treated other contributors to Niger Delta history with similar intolerance. In a previous review of Dr. K. O. Dike's Trade and Politics in the Niger Delta (Africa, vol. xxvii, no. I, pp. 83-85), he had insisted that certain sections of the book needed to be "revised" and unless that was done, the book would be unfair to the Bonny people! In the final paragraph of his present review, he goes beyond attack of my alleged unfairness to the Nembe state to impugn the scholarly integrity of all who had dared to encourage my first efforts.

'Mr. Jones's claims to be an authority on Niger Delta history are based on a number of years in the Nigerian administration (none of which seem to have been spent in the delta), 
and a period of six weeks of field-work " in the Eastern delta in 1956 ".' And from this position he is able to suggest that my membership of the society and three years of work in the Nigerian National Archives were insufficient to produce a book. Most of his detailed criticism is equally unreliable.

'Mr. Jones did not know that there is a cheaper paperback edition at Ibadan when he criticized the book as "sumptuously produced" and too expensive for local readers. He is also wrong in his statement that the Brass District of my third map gave no indication of the Nembe state. The Brass District does represent the core area of the state, and the Brass Division something of the outlying districts under the direct influence of that state.

' His criticism of Chapter 2 amounts to an invitation to write a full scale ethnography of Nembe, beyond the requirements of an introductory sketch to a simple historical survey. Mr. Jones seeks to count my membership of the society against me. He asks me to give more weight to a chieftaincy dispute between Ogbolomabiri and Bassambiri than it deserves. A full government report of the dispute is already in print and in the possession of most Nembe people. ${ }^{2}$ This was cited and the relevance of the dispute to Nembe history discussed. Mr. Jones would require me to treat the Nembe state as composed solely of Ogbolomabiri and Bassambiri, to the neglect of the important coastal communities of Okpoma, Twon, and Odioma. (Mr. Jones confines his own description of the Kalabari and Ibani states to the towns of Elem Kalabari and Bonny, and his "Ijo" does not include the zo-odd sub-groups to the west.) He also criticizes my discussion of the house system on wrong premisses. He wants me to "describe the actual organization and functions of a Nembe house". One could ask at what point in time would Mr. Jones recognize a Nembe house as "actual ". One would have thought that the eye-witness account of the institutions in the nineteenth century and the conceptions of it in the early twentieth, that formed the basis of government, were relevant to history. His comments that in Chapter 3 on oral traditions I had " selected some and ignored others " would apply more appropriately to his own use of oral tradition. He refers to the traditions he chooses as the "authorized version"-a convenient device to avoid discussing the truly " interesting point " of variant versions of oral tradition.

"Contrary to Mr. Jones, there was nothing sudden or mysterious about my dates for King Amakiri of Kalabari and King Pepple of Bonny. Both dates were taken from Talbot and acknowledged in the notes. He also questions the propriety of using king lists to indicate time perspective. He has not convinced me that king lists are useless. His challenge of my Nembe dates does not amount to much. His comments on the lists refer to the Bassambiri list rather than to the Ogbolomabiri list which I had used. He says only dates after Mein of Bassambiri and Amain of Ogbolomabiri are reliable, but does not realize that Mein's contemporary in Ogbolomabiri was Kulo, Amain's father. There are, accordingly, dates for Kulo in at least Richard and John Lander (1830). ${ }^{3}$

'Mr. Jones implies criticism of Chapter s from a single mis-statement of the indications of two useful tables. The point that should have been made was that the ports of Brass and Akassa failed to develop as rapidly as did such rivals as Old Calabar, Bonny, Forcados, and Sapele. They soon ceased to be reckoned ports, and the customs house at Akassa was removed in 1933 . The decline of these ports was relative to the other ports which eventually took over all their business.

"Mr. Jones suggests the "revision" of a single paragraph in Chapter 7, but the "impression" he wishes to use as revision material had already been stated at page 57 of the book.

"Mr. Jones concludes that my material was "unprepared", and that those who had

I G. I. Jones, The Trading States of the Oil Rivers (London, 1963), p. vi.

2 O. Ukelonu, Report of the commission of inquiry into the Nembe chieftaincy dispute (Official document
No. 24, Enugu, 1960).

3 Richard and John Lander, Journal of an expedition to explore the course and termination of the Niger... (London, 1834). 
helped me to publish it " were rendering no service to Nigerian historical scholarship or to their reputation". Mr. Jones would need to present better credentials for his claim to be the sole judge of standards, services, and reputations in Nigerian historiography.'

Professor Jan Vansina (Department of History, University of Wisconsin) writes:

'Concluding his rather derogatory review of J. Alagoa's The Small Brave City-State: a History of Nembe-Brass in the Niger Delta, Mr. G. I. Jones states that " those responsible for directing his [Alagoa's] research should have realized that by supporting publication of his material in this unprepared form they were rendering no service to Nigerian historical scholarship or to their reputation ". As one of the persons concerned, I must state that I welcomed publication of the manuscript because $(a)$ it is based on field-work and a long knowledge of the area, and (b) it is a modest contribution to local history-and this book is just that. These local histories are the very foundations of our historical knowledge and they must be encouraged and published.

"There is nothing " unprepared" about this and the reviewer errs when he has it that the author is now engaged in field-work in that area. Dr. Alagoa did field-work in $1963-4$ to collect materials for his Ph.D. on "The Settlement of the Niger Delta ". The only overlap with this study is pp. 34-50: "Legends of origin." Of course the monograph could have been more perfect-could not all monographs? - but then we also realize that too many worthy manuscripts have been buried because of an appeal to so-called "standards".

'Petty reviews such as this one set back the cause of scholarship rather than promote it. For they try to penalize the historian-professional or amateur-who is bold enough to gather basic data in his field. In fact such reviews make one only wonder what moves the display of such harshness.'

Mr. G. I. Jones replies:

'I am sorry to have to hurt people's feelings but I stick to my guns. I don't think that Dr. Alagoa has really answered or understood my critcisms. I am not concerned with "staking out claims to territory" but with standards of Nigerian historical scholarship. I fully endorse Professor Vansina's assessment of this book. It is, as he says, 'a modest contribution to local history.'

\section{East Africa and the Orient: Historical Problems of the Pre-Colonial Era}

A CONFERENCE on this subject will be held from $s$ to 9 April 1967 at the British Institute of History and Archaeology in East Africa, Nairobi, under the sponsorship of the Harvard University Center for International Affairs (Convenor, Robert I. Rotberg), and the British Institute (Convenor, H. Neville Chittick), financed by the Ford Foundation. The programme will include sessions on: the maritime civilizations of Asia; the dating and significance of the Periplus of the Erythraean Sea; the influence of Indonesia: hypotheses and data; the peopling of the coast; material evidence of cultural connexions between the Orient and Africa; the interior of Africa and the Coast. It is expected that participant speakers will include about thirty scholars from institutions in East Africa, Madagascar, Europe, and U.S.A., and we hope to include a further note on the work of the conference in a later number of $A$ frica.

(See also p. 85). 